\title{
HIID A MÚLT FELETT: ŐSKORI TELEPÜLÉSNYOMOK, RÓMAI KORI TEMETŐ ÉS KORSZAKOKAT ÖSSZEKÖTŐ ÉPÍTMÉNY AZ ÓBUDAI DUNA-PARTRÓL Beszámoló a Graphisoft Park bővítéséhez kapcsolódó régészeti feltárások friss eredményeiről
}

\section{Hajdu Barbara ${ }^{1}$ - Tóth Farkas Márton ${ }^{2}$}

Magyar Régészet 9. évf. (2020), 4. szám, pp. 13-21. doi: https://doi.org/10.36245/mr.2020.4.4

\begin{abstract}
Budapest III. kerületében, a Graphisoft Park bővítése kapcsán a Budapesti Történeti Múzeum részéröl folytattunk megelözö feltárásokat 2019 szeptemberétöl december közepéig, majd 2020 március végétöl augusztus közepéig, az óbudai Duna-part Aquincumhoz közeli részén (1. kép). Az ásatások során egy összetett, többkorszakú, helyenként többrétegü lelöhely részletei bontakoztak ki, amely bár régóta ismert és kutatott, igy is böven tartogatott izgalmas, elöre nem látott meglepetéseket, melyekröl az alábbiakban kívánunk röviden beszámolni. ${ }^{3}$
\end{abstract}

Az Aquincum polgárvárosától keletre elterülő területen már az 1830-as években felfedezték az első sírokat, majd újabb leletmentő ásatások folytak Kuzsinszky Bálint vezetésével a 19. század végén (Kuzsinszky, 1892). A 20. század elején a Gázgyár építéséhez kapcsolódóan megszaporodtak a régészeti munkák a területen, ezek során előkerült a római kori fazekastelep és több mint 100 temetkezés is napvilágot látott. Az első módszeres feltárások 1996-ban, a Graphisoft Park építéséhez kapcsolódva kezdődtek meg Zsidi Paula vezetésével (Zsidi, 1997), majd Lassányi Gábor irányí-

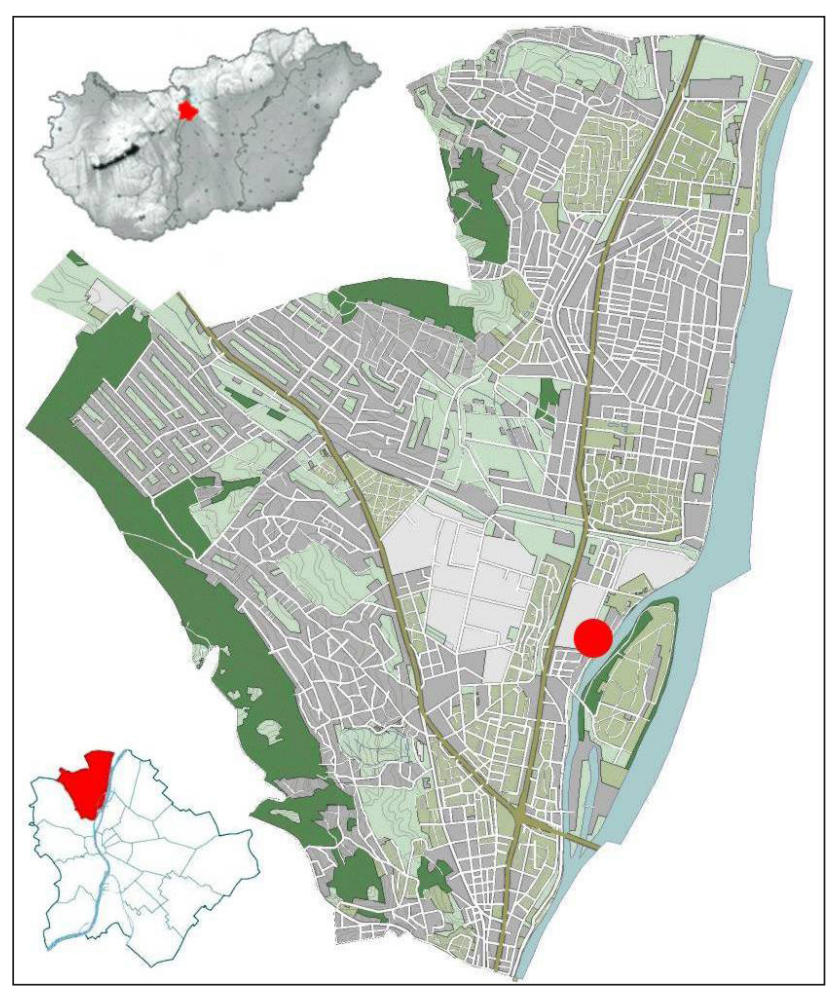

1. kép. A 2019-2020. évi feltárások helyszine Magyarország, Budapest és a III. kerület térképén (készitette: Tóth Farkas Márton) tásával folytak tovább 2017-ig (LASSÁNYI \& SzEREDI, 2020). ${ }^{4}$ Az ásatásoknak köszönhetően egyre részletesebben körvonalazódott a polgárvárostól keletre található római kori ipartelep, illetve az attól délebbre található többkorszakú őskori lelőhely és a mára több mint 1500 sírt számláló római kori temető.

Az idei és tavalyi évben három munkaterületen (2. kép) nyílt ismét lehetőségünk régészeti kutatásokra. Ezek során $5923 \mathrm{~m}^{2}$ nagyságú területen 398 rétegtani egység feltárását végeztük el.

Régész, BTM Aquincumi Múzeum, Ókortörténeti Főosztály. E-mail: hajdu.barbara@aquincum.hu

2 Régész, főosztályvezető-helyettes, BTM Aquincumi Múzeum, Ös- és Népvándorlás kori Főosztály. E-mail: tothfarkasmarton@, gmail.com

3 Ez úton is szeretnénk kifejezni köszönetünket a feltárás során végzett nélkülözhetetlen munkájukért Arany Attila gépkezelőnek és Vígh Piroska müvezetőnek (SB Dynamic Kft.), a kézi földmunkát biztosító vállalkozások valamennyi résztvevőjének (Salisbury Kft., Club Sixty Kft.), Láng Orsolya, Vukics Adrienn, Lamm Flóra és Fuchsz Noémi régész munkatársaknak, a BTM Ásatási Projektiroda régésztechnikusainak (elsősorban Kelemen Zsófiának, Virágh Leventének és Schmidt Nikolettnek), Fábián István, Kovács Tibor és Imre-Horváth Sándor geodétáknak, valamint a 2019-es évad drónfelvételeit készítő Rupnik Lászlónak (ELTE Régészettudományi Intézet). Köszönjük konzulenseinknek, Lassányi Gábornak és Zsidi Paulának, hogy értékes tanácsaikkal segítették munkánkat. Köszönjük továbbá a Graphisoft Parknak (különösen Drágán Mariannának, Huber Rolandnak és Kocsány Jánosnak), hogy a feltárást és az egyedülálló emlékek megtartását támogatták és segítették.

4 A Gázgyár és a Graphisoft Park területén végzett korábbi feltárások eredményeiről szóló előzetes közlések az Aquincumi Füzetek hasábjain jelentek meg. A kutatástörténet bővebb összefoglalásához lásd: LASSÁNYI \& SzEREDI, 2020. 


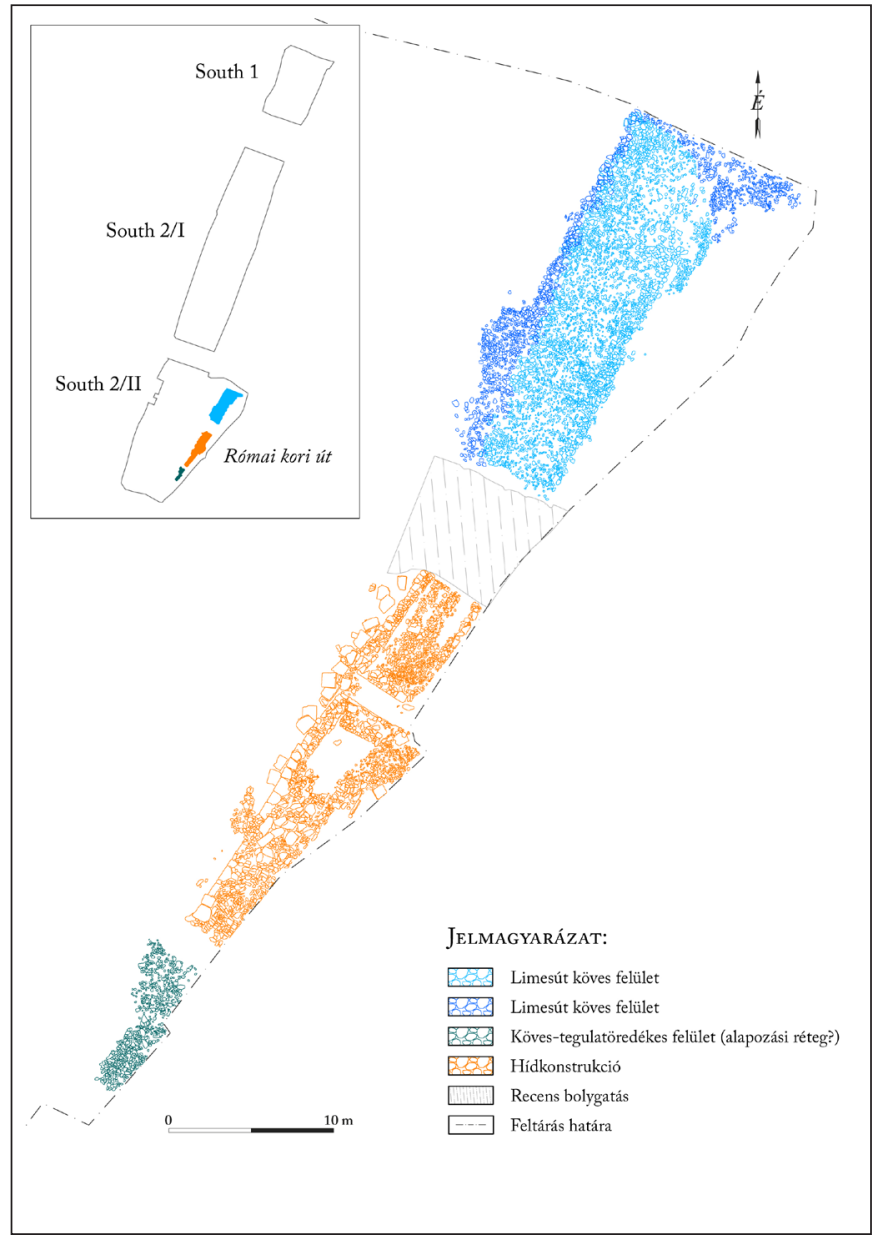

2. kép. A feltárt limesút-szakasz felmérési rajza (készítette: Juhász Gergö, Poptiuc Edina, Lowpoly 360 Kft.) és a Graphisoft Park bövitését megelözö 2019-2020. évi ásatási munkaterületek áttekintő rajza

(készitette: Fábián István, Kolozsvári Krisztián)

\section{A FÖLDRAJZI KÖRNYEZET}

A lelőhely sokszínű és mozaikszerü régészeti topográfiai képét, az újkőkortól meglevő intenzív területhasználatot alapvetően határozzák meg a természetes geomorfológiai adottságok: az óbudai Duna-parton fekvő, az ártérből kiemelkedő folyóhátak és hordalékkúpok. A feltárási területek a Duna Óbudai-szigettel szemközti, jobb parti sávjában, az 1914-ben épült gázgyári tisztviselőtelep mellett, annak délnyugati részén helyezkedtek el. A déli területrészen a jelenlegi talajfelszínt alkotó recens feltöltés alatt előkerült régészeti lelöhely a mellékágat kísérö, keskeny folyóhát és egy délnyugati irányban húzódó, szélesebb kiemelkedés közti, É-ÉNy - D-DK-i irányú, óholocén Dunaág partján és annak részben feltöltődött medrében fekszik. Ez az egykori, vízjárta terület az elmúlt évek környezettörténeti kutatásainak köszönhető jelenlegi ismereteink szerint a Csillaghegyi-árok - Mocsárosdülő - Óbudai-sziget vonalában alkotott egybefüggő vízrendszert (PÁlL, TóTH \& Sipos, 2017; Тóтн et al. 2019).

Ez a térség a rézkortól a római kor szárazabb, melegebb éghajlati periódusáig (1-3. század) részben a Duna nagyobb kiöntései, részben a hegylábi régióból érkező csapadékvizek által táplált, csak időszakosan vízjárta, ritkán víz borította, ingoványos, ártéri zónaként rekonstruálható, melynek összeköttetése a Dunával a feltárási terület déli végének környezetében lehetett. Ezt a mélyebb térszínt megfigyeléseink szerint a római koron belül lezajló, ismert éghajlat változási folyamatokkal (GRÜLL, 2017, 64-66), a Duna vízhozamának növekedésével, szélsőséges áradásainak gyakoribbá válásával összefüggésbe hozható hordaléklerakódás tagolta. Az egykori meder kitöltésének átvágása során megfigyelt steril, nagy vastagságú üledékréteg a római kori szinteket kettéosztja. A lerakódó folyóvízi üledék által képzett folyóhát régészeti topográfiai szempontból a késő római időszakra vált meghatározóvá.

A feltárási terület északi része más képet mutat, az őskori és római kori régészeti jelenségek itt az Aranyhegyi-patak torkolatától déli irányban húzódó, egykori homokos kiemelkedés délnyugati lejtőjén helyezkedtek el. Lelőhelyünk ezen része tehát földrajzi és régészeti topográfiai szempontból is szorosabb összeköttetést mutat a Graphisoft Park építését megelőzően korábban itt végzett kutatások során feltárt jelenségekkel (LASSÁNYI \& SZEREDI, 2017).

A feltárás során előkerült római kori út és a híd, valamint ezek környezetének geomorfológiai, környezettörténeti viszonyainak rekonstruálása céljából talajfizikai, geokémiai vizsgálatokra (Viczián István, CsFK Földrajztudományi Intézet), az üledékrétegek és az egykori Duna-ág menti táj változásainak keltezése érdekében pedig OSL (optikai lumineszcencia) mérések céljából történt mintavétel (Sipos György, SzTE). Ezek eredményeitől azt reméljük, hogy az itt feltárt jelenségeket a szükebb és tágabb környezetével és annak változásaival együtt értelmezve sokkal pontosabb és világosabb képet festhetünk az óbudai Duna-part ezen részének elmúlt két évezredben lezajlott történetéről. 


\section{AZ ŐSKORI MEGTELEPEDÉS NYOMAI}

A déli feltárási területen (South 2/I-II. ütem) talált legkorábbi megtelepedés nyomait a középső neolitikumra, illetve a rézkorra keltezhető edénytöredékek jelentik, e korszakokból jól datálható, zárt objektum nem volt megfigyelhetö. A kora bronzkori és késő vaskori (La Tène D) megtelepedés nyomait a szórványleletek (pl. egy a Kr. e. 1. századra kel-

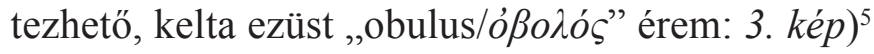
mellett néhány bolygatott telepobjektum jelentették. Egy melléklet nélküli, zsugorított csontvázas temetkezést feltételesen a kora bronzkor idejére tehetünk a Graphisoft Park északabbra eső fejlesztési területein ismertté vált, a harangedényes kultúra Csepel-csoportjához tartozó temetkezések alapján (LASSÁNYI, 2011, 36-39). Az őskori jelenségek hiányát és a leletek szórványos előkerülését minden bizonnyal a rendkívül intenzív római kori területhasználattal és a korábbi időszakok rétegeinek ebből fakadó erőteljes bolygatottságával magyarázhatjuk.

Az északi területrészen (South 1) is a középső neolitikus edénytöredékek jelentik a legkorábbi horizontot. Az itt feltárt jelenségek nagyobb részéből azonban a kora és középső bronzkorra keltezhető leletanyag látott napvilágot. Az ebből az időszakból származó telepobjektumok főként különböző méretü és mélységü, kerekded tároló- vagy szemetesgödrökként képviselték az őskori megtelepedés földbe mélyített nyomait. Egy kora bronzkori - valószínúleg másodlagos helyzetben, az altalaj feletti humuszrétegben fekvő - ép korsó (4. kép) és kevés szórvány bronzlelet feltehetően bolygatott sírok mellékleteiként értelmezhető. Az őskor utolsó, területen megfigyelt periódusát néhány, a késő bronzkori urnamezős kultúra edényművességéhez tartozó töredék képviseli.

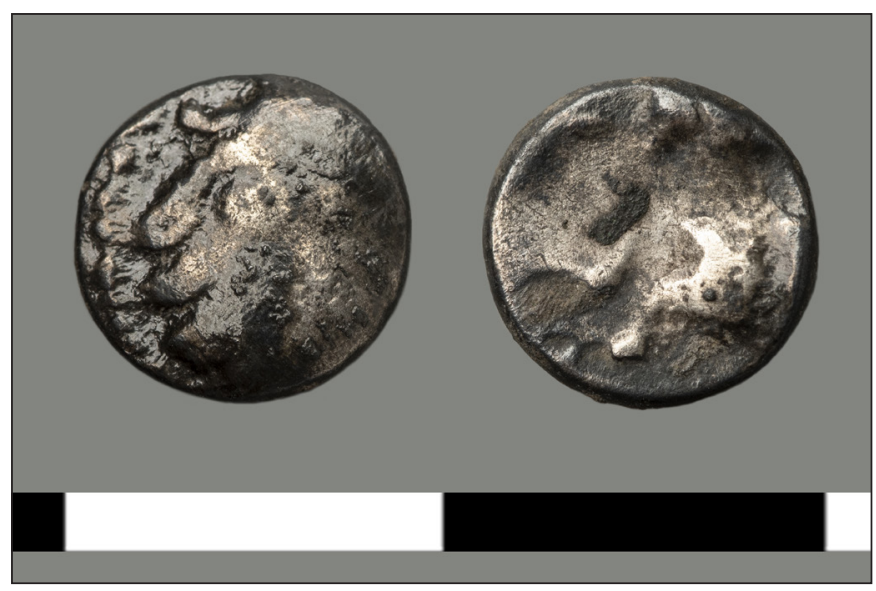

3. kép. Kelta ezüstérme (,,obulus/ößoגóৎ”) a Kr. e. 1 . századból (restaurátor: Újvári Gábor; fotó: Szilágyi Nóra; BTM Aquincumi Múzeum)

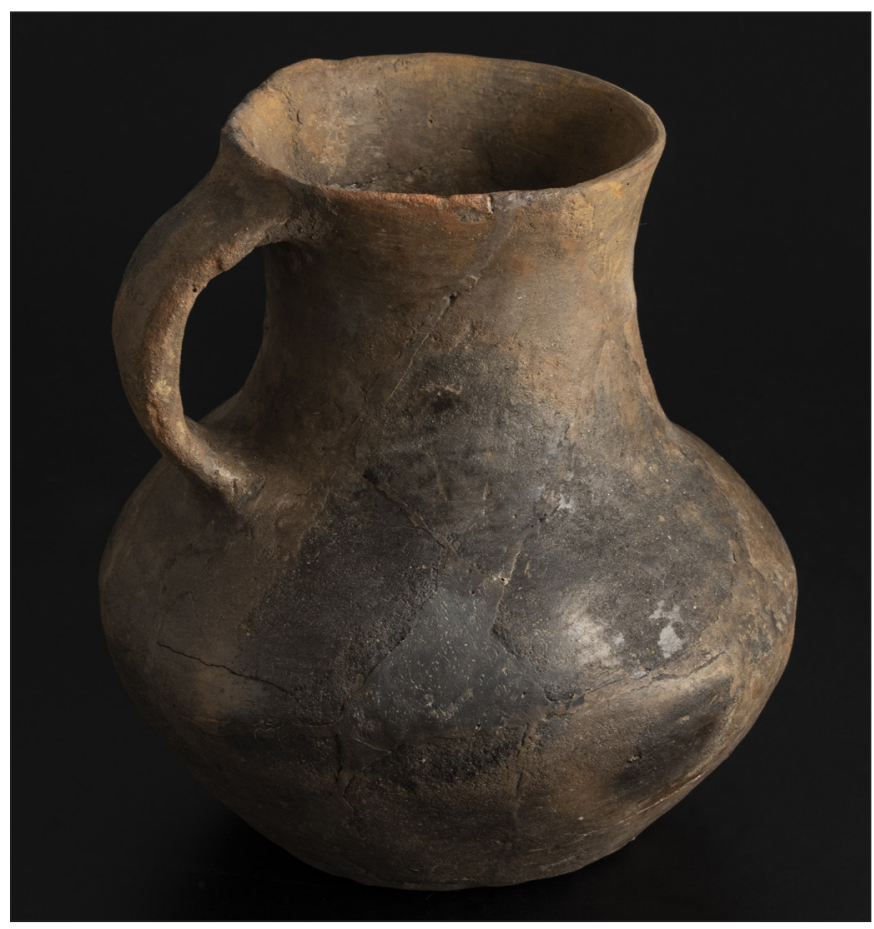

4. kép. Kora bronzkori temetkezéshez köthetö korsó a Kr. e. 3. évezred második feléből (restaurátor: Heincz Katalin; fotó: Szilágyi Nóra; BTM Aquincumi Múzeum)

\section{A RÓMAI KORI TERÜLETHASZNÁLAT EMLÉKEI}

Mindhárom munkaterületre kiterjedt az aquincumi polgárváros keleti temetője, amely a város keleti-délkeleti elöterében került kialakításra. A nekropolisz az 1. század vége és az 5. század között volt használatban. A temetőben a korai hamvasztásos rítusú sírok mellett a 2. századtól előtérbe kerülő csontvázas sírok is megtalálhatók.

A temető déli részén a római korra keltezhetően legalább két periódust lehetett elkülöníteni egymástól. A leletanyag előzetes vizsgálata alapján az 1-2. századra tehető időszakban nagyméretủ agyagnyerő gödörkomplexumokat ástak ki, majd a terület funkcióváltását tapasztalhatjuk, és a 2-3. századtól itt is temetkezni kezdtek a polgárváros lakói.

\footnotetext{
A meghatározásában és keltezésben nyújtott segítségét ez úton is köszönjük Torbágyi Melindának (Magyar Nemzeti Múzeum).
} 
Hajdu Barbara - Tóth Farkas Márton • Híd a múlt felett

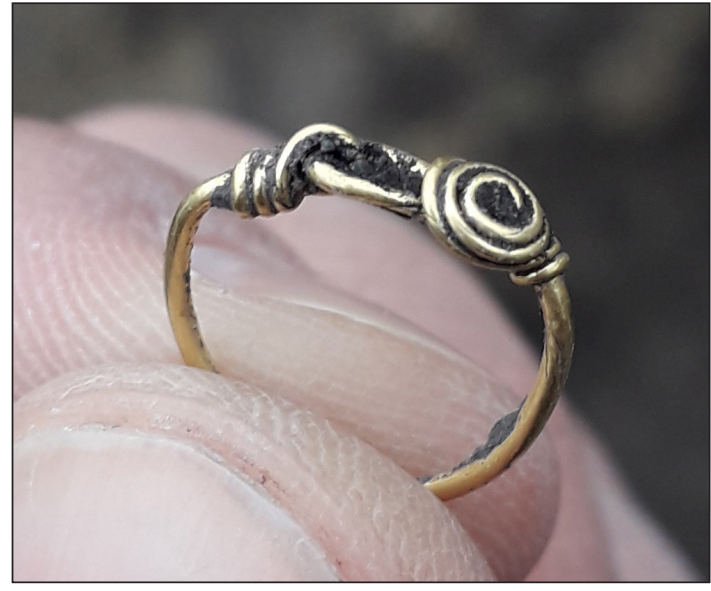

5. kép. Római kori hamvasztásos sírból származó arany fülbevaló (fotó: Tóth Farkas Márton)

A feltárás során 76 római kori sír került elö, amelyek rítusa és tájolása változatos képet mutatott. A Duna közelsége miatt kialakult vizenyős, iszapos közeg több esetben jó állapotban megőrizte az elhunytakra helyezett fadeszkákat, amik kiváló adatokkal szolgálnak számunkra a római kori temetkezési szokásokkal kapcsolatban. A sírmellékletek között a leggyakrabban kerámia- és üvegedények, mécsesek, érmek, fibulák, cipöre (caliga) utaló vasszegecsek, illetve különféle ékszerek kerültek elö. E tárgyak közül egy hamvasztásos sírban talált arany fülbevaló képviselhetett jelentősebb értéket (5. kép).

A szórványleletek nagy számát elsősorban Sándor Lajos fémkeresős kollégánknak köszönhetjük, aki több mint kétszáz fémtárggyal gyarapította gyüjteményünket. Ezek közt kiemelkedő leletnek számít egy, a késő római katonai viselethez köthetö, aranyozott hagymagombos fibula, valamint a vízpart és az ártér adottságainak kihasználására utaló bronzhorog, ami az iszapos mederbetöltés pereméről került elö. A terület római kort követő folyamatos használatának egyik bizonyítéka a South 2/II. ütem délkeleti sarkában feltárt dél-északi irányú sekély árok, amelyből avar korra keltezhető kerámiatöredékek láttak napvilágot. ${ }^{6}$

\section{A LIMESÚT}

Az idei ásatási idény a korábbi eredményekhez képest is nagy meglepetéseket, szakmai és laikus szemmel egyaránt szenzációsnak nevezhető leleteket tartogatott számunkra, ugyanis a fent említett temetőrészlettől délkeletre napvilágot látott a Római Birodalom határvédelme szempontjából alapvető stratégiai jelentőséggel bíró limesút egy eddig ismeretlen részlete (2. kép). Az út pannoniai szakasza a Duna vonala mentén elhelyezkedő katonai létesítmények és települések egymással való összekötésében, ezáltal pedig az ellátmány és a katonai utánpótlás zavartalan biztosításában játszott fontos szerepet.

A Duna-menti határvédelmi rendszer, azaz a ripa Pannonica magyarországi szakaszának létrehozása a Flavius-korra tehető, Aquincum területén pedig az 1. század utolsó negyedében épült ki (BorHy \& SzABó, 2015, 110). Az Aquincumon áthaladó limesút az 1-2. században a mai Szentendrei út vonalán futott (ZsIDI, 2002, 135, 138), majd a 3. század elején a polgárvárostól keletre, a Dunához közelebb eső területre helyezték át (ZsIDI, 2002, 138-139; VISY, 2003a, 39) (6. kép). Más birodalmi útakhoz hasonlóan a limesutat is a katonaság építette, majd tartotta karban a római kor folyamán.

$\mathrm{Az}$ ásatás során előkerült É-D-i tájolású, 64 méter hosszú, nagyméretü kövekből megépített útszakasz helyenként elérte a 10-12 méteres szélességet (7. kép). A feltárt útrészletet - a limesút Pannonia területén ismert szakaszai

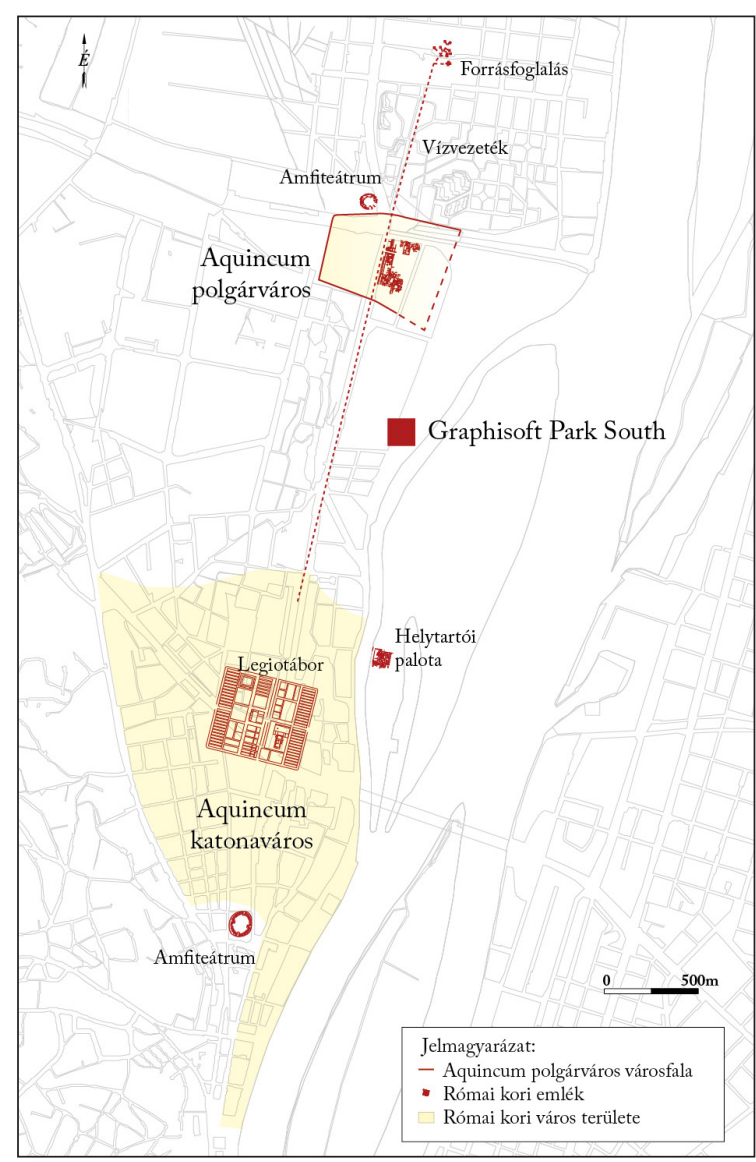

6. kép. A feltárás helyszine Aquincum római kori topográfiáját ábrázoló térképen (készitette: Kolozsvári Krisztián)

6 Köszönjük Mészáros Boglárkának (BTM Aquincumi Múzeum) a kerámia meghatározását. 


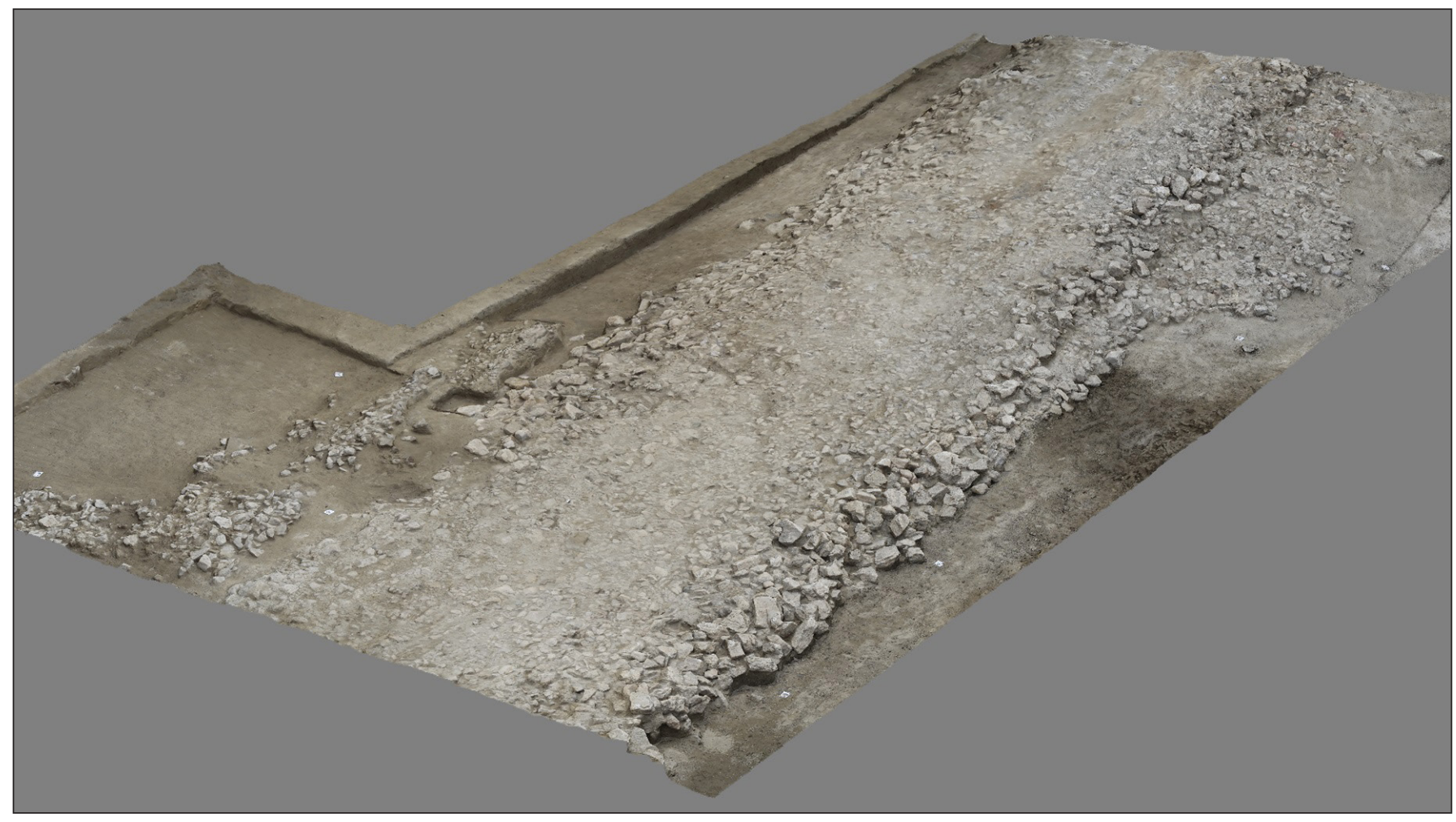

7. kép. A limesút északi szakaszának 3 dimenziós képe (készitette: Gyurics Balázs, Juhász Gergö, Lowpoly 360 Kft.)

közül - az egyik legjobb állapotban megmaradt konstrukcióként tarthatjuk számon. Északi, a polgárvároshoz legközelebb eső részén ez a masszív struktúra körülbelül $70 \mathrm{~cm}$ vastagságban köves rétegekből állt, ami föként a fontosabb katonai táborokon és nagyobb településeken belül figyelhető meg (VISY, 2003b, 133). A mi útszakaszunk topográfiai helyzetéhez hasonló külvárosi, rurális környezetben általában inkább a kavicsos, sóderes földutak jellemzőek.

Az út felületén megfigyelhetővé váltak kocsikerekek és építési törmelékkel javított kátyúk nyomai, ami nem meglepö, hiszen ezen a stratégiai és kereskedelmi szempontból fontos útvonalon akár több tucat kocsi járhatott naponta, illetve a katonai csapatok is ezen közlekedtek az erödítmények között. A gyakori igénybevételből adódó kopásnyomok és javítások már a feltárás kezdetén arra utaltak, hogy az út használatának ideje, folyamatos karbantartás mellett, legalábbis évszázadokra tehető.

Az út északi és középső szakaszát recens csatornák nyomvonala szakította meg, de ezáltal kitünően vizsgálhatóvá vált szerkezetének metszete. Megfigyelhettük a római kori útépítés egyik sajátos vonását, vagyis, hogy az út középtengelyét nagyméretủ kövekkel jelölték ki, ${ }^{7}$ majd erre építették fel az úttest rétegeit. Kivitelezéskor az optimális vízelvezetés elérése miatt törekedtek rá, hogy az útfelület domború (ún. bakhátas) kialakítású legyen. Általában az utakkal párhuzamosan, annak két oldalán egy-egy vízelvezető árkot ástak az építők, de mivel ez az útszakasz egy, a környezetéből kiemelkedő folyóhátra épült fel, így a helyi adottságok kihasználása révén erre nem volt szükség, a csapadék és a Duna áradásai által megjelenő víz a töltés oldalán szabadon lefolyhatott. A római korban a mocsaras, vízjárta környezetben gyakran helyezték kiemelkedésekre az utakat, melyeket bizonyos esetekben akár mesterséges tereprendezéssel is kialakíthattak (VISY, 2003a, 45).

A jelenlegi feltárástól északabbra, az egykori Gázgyár területén, Zsidi Paula által folytatott ásatások során eddig két ízben - 2000-ben (ZSIDI, 2001, 78) és 2002-ben (ZsIDI \& REMÉNYI, 2003) - került elő egyegy, a miénkhez hasonló tájolású útszakasz, melyek szintén a Duna partján húzódó kiemelkedésre épültek, viszont nem rendelkeztek kőburkolattal. Keltezésük bizonytalan, ezért az idei évben előkerült limesúthoz csak feltételesen kapcsolhatók.

Ezúton is köszönjük Bödöcs Andrásnak (ELTE BTK Régészettudományi Intézet) az útszerkezet értelmezésében nyújtott segítségét. 
Hajdu Barbara - Tóth Farkas Márton • Híd a múlt felett

Az útszakaszon és az alatta található dombháton több helyen metszeteket alakítottunk ki, hogy jobban vizsgálható legyen az építmény szerkezete, kronológiája. Az egyik átvágásból 2. századra keltezhető, színházi maszkot ábrázoló terrakotta antefix (tetődísz) és egy kémény díszítésére szolgáló ún. „világítótoronymodell” töredéke került elö a kövek közül, másodlagosan felhasználva. A konstrukció 3. századi keltezését az út felületéről, a kövek közé taposva elökerült, Severus Alexander ezüst denariusa (222-228) bizonyítja. ${ }^{8}$

A limesút ezen szakaszának a római kor után is - összesen mintegy 1200 éven át - fennálló, ${ }^{9}$ jelentős szerepét az útfelületen és a nyomvonal mellett előkerült középkori és kora újkori kocsialkatrészek, vaspatkók mutatják. A római kori határvédelmet követően az Árpád-kortól adatolhatóan ismét felértékelődött az út - feltehetően a Buda és Visegrád közti közlekedés szempontjából fontos - szerepe. Ezt támasztják alá II. Géza (1130-1162), és I. Lajos (1342-1382) érméi, illetve egy I. Ferdinánd (1526-1564) vereteiből álló kis éremlelet, melyek az út közvetlen környezetében kerültek felszínre.

\section{A HÍDSZERKEZET}

Az északi útszakaszt bolygató recens csatornától délre, a kövezett útfelület alatt sorba rendezett facölöpökkel alátámasztott, nagyméretü, négyszögletes keresztmetszetü, egymáshoz csapolt fagerendákra épített falak kerültek elő. A kezdetben nehezen értelmezhető konstrukció rétegről rétegre való bontása során egyre közelebb kerültünk az összetett rejtvény megfejtéséhez, míg végül világossá vált: a faalapozású kőfalak egy, az úthoz szervesen kapcsolódó hídszerkezethez tartoztak (8. kép). A híd egy 1,5 m széles - az útra merőleges - Duna felé vezető áteresztő nyílás felett ívelt át egykor. A hídszerkezettől északra található útszakaszt kisebb, a déli szakaszt pedig nagyméretủ kövekkel burkolták. Ez utóbbi két szélét masszív, négyszögletesre faragott kőlapokkal szegélyezték. A híd egykori boltozatának néhány ívesen faragott kőelemét később, a 18-19. században, egy felette felépített, téglaboltozatos áteresz szerkezetéhez használták fel, így ezeket másodlagos helyzetben találtuk meg. Az eredeti boltív alsó részének vonalát a még álló építmény feltöltő-

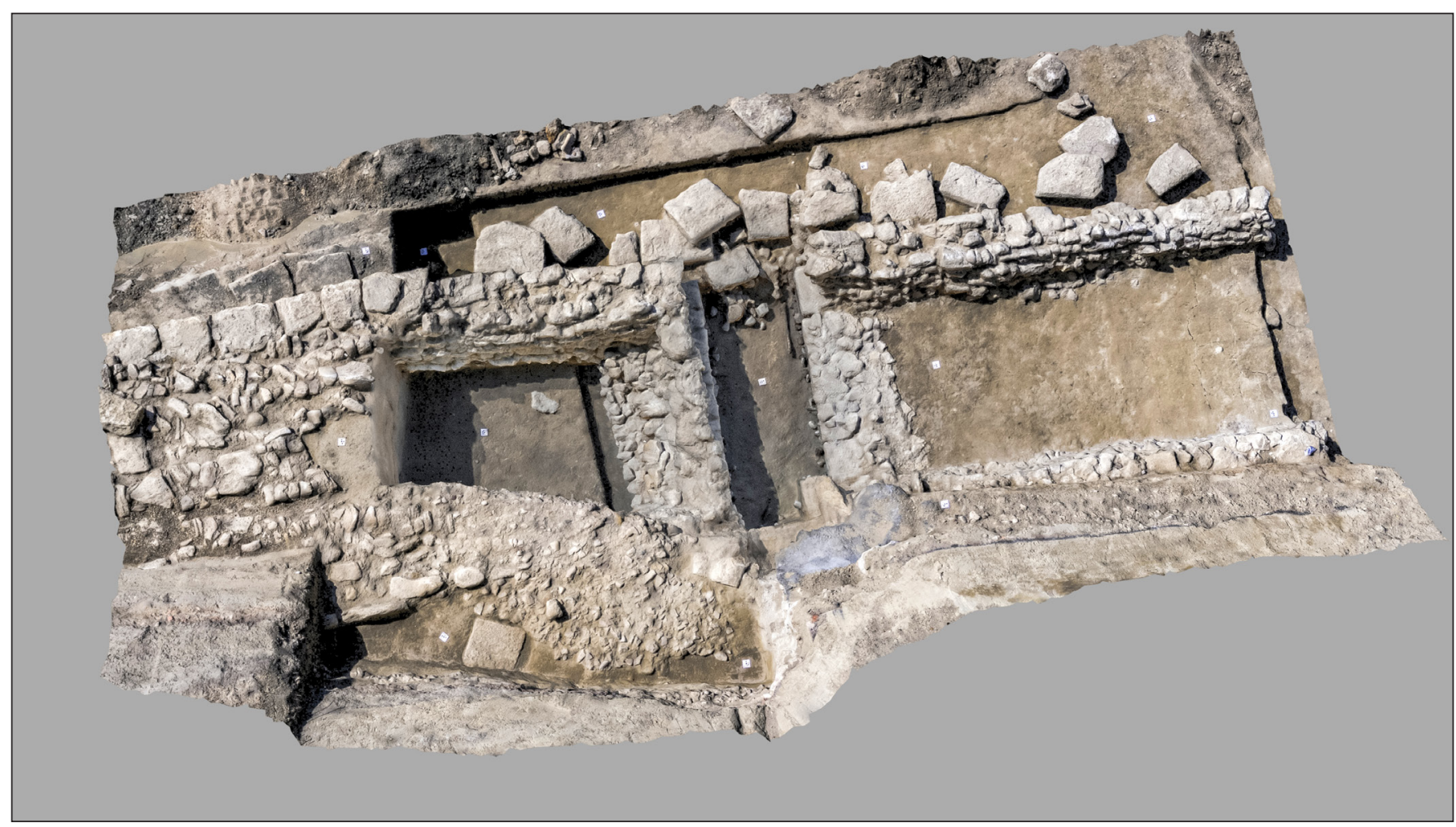

8. kép. A töltésfalakkal övezett hídszerkezet és a rajta átvezető limesút középsö szakaszának 3 dimenziós képe (készitette: Gyurics Balázs, Juhász Gergö, Lowpoly 360 Kft.)

8 A meghatározásért Juhász Lajosnak (ELTE BTK Régészettudományi Intézet) tartozunk köszönettel.

9 Több magyarországi útszakasz esetében megfigyelhető, hogy a római kort követően még évszázadokon keresztül használatban maradtak (lásd: PETÖ, 2014). 
Hajdu Barbara - Tóth Farkas Márton • Hid a múlt felett

dése által létrejött réteghatárként figyelhettük meg a hídnyílás (áteresz) keleti metszetfalában, így a híd boltozata rekonstruálhatóvá válhat. Az építmény építészeti szempontból legközelebbi párhuzama, a nemrég napvilágot látott útszakasztól valamivel délebbre, a Mozaik utca térségében 1978-79-ben részlegesen feltárásra került hasonló, szádfalas technikával készült hídfőállás, ahol egy cölöpsor futott végig a kváderkövekből épült alapozás mellett (ZsIDI, 1999, 258).

A hídnyílás feletti boltozatot támasztó falak, illetve az ettől északra és délre található kőfalak alapozásául szolgáló, faragott, csapolt tölgyfából készült gerendaszerkezet, valamint az ezek megerősítésének érdekében levert cölöpsorok az ártéri üledék által biztosított oxigénhiányos környezetnek

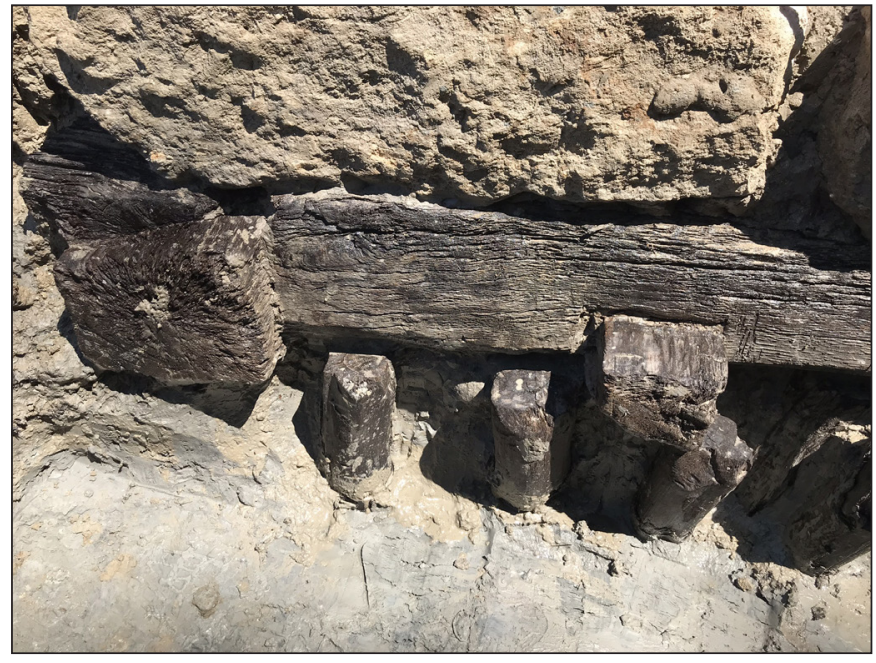

9. kép. Csapolt gerendaszerkezet és cölöpsor részlete hídnyílás északi oldalán (fotó: Hajdu Barbara) köszönhetően kiemelkedően jó állapotban kerültek elő (9. kép). A Duna és egykori mellékága közti folyóháton fekvő híd különleges építési technológiáját indokolta, hogy az erősen vízjárta területen az utat ne mossák alá, a hidat pedig ne döntsék romba az áradások.

A faszerkezetekből vett minták konvencionális radiokarbon kormeghatározásának eredményei alapján az áteresztől északra található hídfö alapozásául szolgáló gerendaszerkezet a római korra (210-345), az attól délre található egyik cölöp 1482-1645 közé, a déli hídfő nyugati oldalfalának alapozásában található gerenda pedig 1402-1459 közé volt keltezhetö (Sipos György, SzTE). Ez az eredmény rávilágított arra, hogy a római korban a limesút részeként felépült, majd a folyamatos használat és talán az árvizek pusztító hatása miatt leromlott állagú hidat a késő középkorban - kora újkorban a déli hídföt érintően részben megújították, megerősítették. Talán ehhez az eseményhez köthető az a vasból készült, famegmunkáláshoz használt véső, amely a megbolygatott töltés egyik talajrétegéből került elö.

A szénizotópos datálás pontosítása érdekében Grynaeus András (Magyar Dendrológiai Laboratórium) segítségével dendrokonológiai mintavételre került sor. A famaradványok xylotómiai vizsgálata alapján a faszerkezet döntő részéhez kocsányos tölgyet, a cölöpök egy részéhez kocsánytalan tölgyet használtak. Az évgyürükből összeállított adatsorok abszolút keltezésre nem bizonyultak alkalmasnak, viszont alátámasztották, hogy az északi és déli hídfő keleti oldalának faszerkezetét azonos időszakban készítették és ezeket a részeket nem érintette a későbbi felújítás. A hídszerkezet javításához a kétirányú vízjárásnak és a nagyobb áradásoknak erősen kitett építmény állagromlása, illetve az útvonal változatlan fontossága, tehát a további használhatóság fenntartásának igénye együttesen vezethetett. A lokális felújítás valószínüleg azzal magyarázható, hogy az ártér felől a Duna medrébe visszazúduló víz romboló hatásának a konstrukció nyugati oldala jobban ki lehetett szolgáltatva.

Az út és a hídszerkezet dokumentálásához a rendelkezésünkre álló legkorszerübb módszereket hívtuk segítségül, így a hagyományos régészeti dokumentáció mellett a bontás több fázisában ortogonális drónfotókat készítettünk és a megtisztított szerkezetet fotogrammetriai módszerrel is rögzítettük (Juhász Gergö, Lowpoly $360 \mathrm{Kft}$.). Dokumentációnkat lézerszkenneres felméréssel is kiegészítettük (Kibédy Zoltán, CÉH Tervező, Beruházó, Fejlesztő Kft.).

A feltárt építmény különleges értékét felismerve a Graphisoft Park módosította korábbi építési terveit és az építmény az örökségvédelmi hatóság előírásainak megfelelően elfedésre, visszatemetésre került. Bár helyben való bemutatása technológiai okokból kivitelezhetetlennek bizonyult, azonban a korszerü módszerekkel végzett dokumentálás a virtuális bemutatás lehetőségét biztosítja. Terveink szerint a Graphisoft Park bővítéséhez kapcsolódóan 2019-2020 során lezajlott feltárások eredményeit az Aquincumi Múzeumban rendezendő időszaki kiállítás keretében is bemutatjuk a nagyközönség számára a közeljövőben. 
Hajdu Barbara - Tóth Farkas Márton • Hid a múlt felett

AJÁNLOTT IRODALOM

Bödőcs, A. (2009). Útkutatás a levegőből. In Anders A., Szabó M. \& Raczky P. (szerk.), Régészeti dimenziók: Tanulmányok az ELTE BTK Régészettudományi Intézetének tudományos mühelyéböl (pp. 37-48). Budapest: ELTE Régészettudományi Intézet - L’Harmattan.

H. Kérdő, K. \& Schweitzer, F. (2010). Aquincum. Ókori táj-ókori város. Budapest: MTA FKI.

Kiss, Cs. \& Mocsy, F. (szerk.) (2000). Óbuda évszázadai. Budapest: Better Kiadó.

Lóki, R. \& Szabó M. (2011). A limes-út. In Visy Zs., Szabó M., Lóki R. \& Priskin A. (szerk.), A Danube Limes Project régészeti kutatásai 2008-2011 között (pp. 101-106). Pécs: PTE Régészet Tanszék.

Visy, Zs. (ed.) (2003a). The Roman Army in Pannonia. An Archaeological Guide of the Ripa Pannonica (Translated from Hungarian by G. Bertók). Budapest: Teleki László Foundation.

Visy, Zs. (2003b). The Ripa Pannonica in Hungary (Translated from Hungarian by G. Bertók). Budapest: Akadémiai Kiadó.

Zsidi, P. (szerk.) (2005). Kincsek a város alatt: Budapest régészeti örökségének feltárása, 1989-2004. Kiállitás a Budapesti Történeti Múzeumban 2005. május 27 -augusztus 20. / Treasures Under The City: Survey of the archaeological heritage of Budapest, 1989-2004. Temporary exhibition at the Budapest History Museum 27 May - 20 August 2005. Budapest: Budapesti Történeti Múzeum.

Zsidi, P. (szerk.) (2017). Kincsek a város alatt - Újdonságok a múltból. Budapest régészeti örökségének feltárása 1867 / 2005-2015. Időszaki kiállitás a BTM Vármúzeumban 2017.04.12.-2017.09.17. Kiállitási vezetó és katalógus. / Treasures under the city-Novelties from the past. Revealing the archaeological heritage of Budapest 1867 / 2005-2015. Temporary exhibition in the Budapest History Museum - Castle Museum. April 12 - September 17, 2017. Exhibition guide and catalogue. Budapest: Budapesti Történeti Múzeum.

Magyar Limes Szövetség. http://www.ripapannonica.hu Letöltés: 2020.10.26.

BiBLIOGRÁFIA

Borhy, L. \& Szabó, M. (2015). Magyarország története az ókorban: Kelták és rómaiak. Budapest: L'Harmattan Kiadó.

Grüll, T. (2017). A Római Birodalom gazdasága. Budapest: Gondolat Kiadó.

Kuzsinszky, B. (1892). Római kori temető Aquincumban. Archaeologiai Értesítő 12, 446-448.

Lassányi, G. (2011). Kora bronzkori és római kori temetőrészlet feltárása a volt Óbudai Gázgyár déli részén (Excavation of parts of Early Bronze Age and Roman cemeteries in the southern part of the former Óbuda Gas Factory). Aquincumi Füzetek 17, 36-51.

Lassányi, G. \& Szeredi, A. (2017). Ásatások a Graphisoft Park Déli részén (Excavations in the Southern Part of the Graphisoft Park). Aquincumi Füzetek 23, 81-88. 
Hajdu Barbara - Tóth Farkas Márton • Híd a múlt felett

Lassányi, G. \& Szeredi, A. (2020). Feltárások a volt Óbudai Gázgyár északi részén (Excavations in the Northern Part of the Gas Factory in Óbuda). Aquincumi Füzetek 24, 112-120.

Páll, D. G., Tóth, F. M. \& Sipos, Gy. (2017). Mocsáros természetvédelmi terület (Budapest III. Kerület) földtudományi vizsgálata. In Zatykó Cs., Szilágyi M. \& Szabó M. (szerk.), Történeti táj - Tájrégészet. Eredmények és perspektívák a magyarországi tájrégészeti kutatásban. Absztrakt kötet. 2017. november 6-7 (p. 77). Budapest: Magyar Tudományos Akadémia Bölcsészettudományi Kutatóközpont Régészeti Intézet.

Pető, Zs. E. (2014). Római vagy középkori? Történeti utak a Pilisben. Magyar Régészet 3/3 [2014 Ösz], 1-8.

Tóth, F. M., Páll, D. G., Sipos, Gy., Szilas, G., Viczián, I. \& M. Virág, Zs. (2019). Környezeti változások a Duna egykori mellékága mentén. Interdiszciplináris kutatás Budapest III. kerület, Mocsárosdűlőn. In Tóth

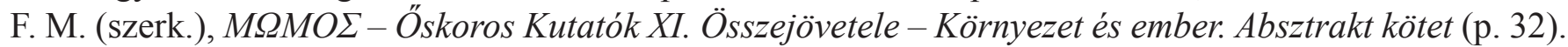
Budapest: Budapesti Történeti Múzeum.

Visy, Zs. (ed.) (2003a). The Roman Army in Pannonia. An Archaeological Guide of the Ripa Pannonica (Translated from Hungarian by G. Bertók). Budapest: Teleki László Foundation.

Visy, Zs. (2003b). The Ripa Pannonica in Hungary (Translated from Hungarian by G. Bertók). Budapest: Akadémiai Kiadó.

Zsidi, P. (1997). Szondázó jellegű feltárás az aquincumi polgárvárostól délkeletre (Test excavations carried out southeast of the Aquincum Civil Town). Aquincumi Füzetek 3, 54-57.

Zsidi, P. (1999). Hídfőállás az aquincumi polgárváros és katonaváros között. In Gaál A. (szerk.), Pannoniai kutatások. A Soproni Sándor emlékkonferencia elöadásai (Bölcske, 1998. október 7.) (pp. 257-274). Szekszárd: Wosinszky Mór Megyei Múzeum.

Zsidi, P. (2001). Kutatások az aquincumi polgárvárostól keletre lévő területen (Research in the territory east of the Aquincum Civil Town). Aquincumi Füzetek 7, 76-84.

Zsidi, P. (2002). Transformation of the town structure in the civil town of Aquincum during the Severi (A. D. 193-235). Acta Archaeologica Academiae Scientiarum Hungaricae 53, 131-149. https://doi.org/10.1556/ aarch.53.2002.1-3.6

Zsidi, P. \& Reményi, L. (2003). Zsidi, Paula-Reményi, László: Duna-parti út részlete és őskori maradványok a polgárvárostól délre (Detail from the road on the Danube bank and prehistoric remains south of the Civil Town). Aquincumi Füzetek 9, 86-94. 